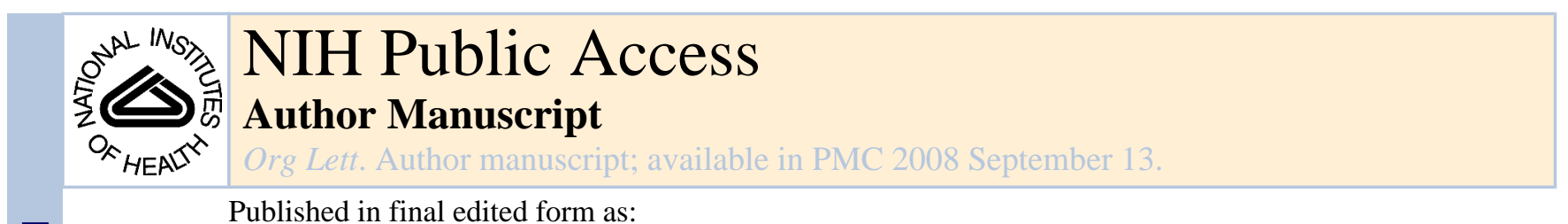

Org Lett. 2006 June 22; 8(13): 2731-2734. doi:10.1021/ol060762k.

\title{
Kinetics of Two-Electron Oxidations by the Compound I Derivative of Chloroperoxidase, a Model for Cytochrome P450 Oxidants
}

\author{
Rui Zhang ${ }^{\dagger}$, Nandini Nagraj ${ }^{\dagger}$, Dharmika S. P. Lansakara-P ${ }^{\dagger}$, Lowell P. Hager $§$, and Martin \\ Newcomb ${ }^{\dagger}$ \\ $\dagger$ Department of Chemistry, University of Illinois at Chicago, Chicago, IL 60607, men@uic.edu \\ $\S$ Department of Chemistry and Biochemistry, University of Illinois at Urbana, Urbana, IL 61801
}

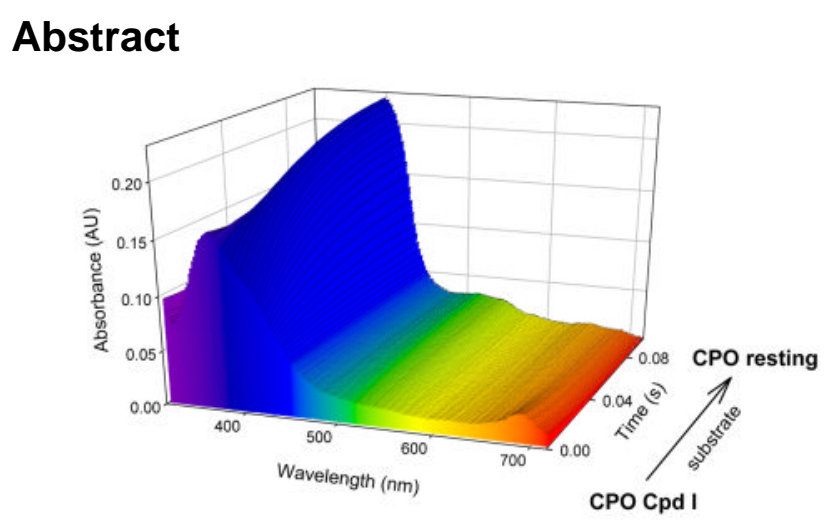

Rate constants for two-electron oxidation reactions of Compound I from chloroperoxidase (CPO) with a variety of substrates were measured by stopped-flow kinetic techniques. The thiolate ligand of CPO Compound I activates the iron-oxo species with the result that oxidation reactions are 2 to 3 orders of magnitude faster than oxidations by model iron(IV)-oxo porphyrin radical cations containing weaker binding counterions.

\begin{abstract}
Enzyme-catalyzed oxidation reactions represent an area of considerable contemporary interest, and oxidations of unactivated $\mathrm{C}-\mathrm{H}$ bonds to give alcohol products are of special interest. The ubiquitous cytochrome P450 enzymes (P450s) hydroxylate unactivated C-H bonds with facility, and these heme-containing enzymes serve as models for practical catalysts. ${ }^{1-3}$ The true oxidants in P450s have not been observed under natural conditions, however, nor do they accumulate to observable amounts under cryogenic conditions when the requisite electrons are provided by $\gamma$-radiolysis ${ }^{4,5}$ or by radioactive decay of phosphorus- 32.6

The oxidant in a P450 enzyme is usually thought to be an iron(IV)-oxo porphyrin radical cation, termed Compound I, by analogy to the intermediates formed in peroxidase and catalase enzymes, ${ }^{7,8}$ but differences exist between the latter enzymes and P450s. The oxidants in P450s are formed by a sequence of reduction, oxygen binding, and protonation steps instead of reaction with hydrogen peroxide, and P450 enzymes contain thiolate from cysteine as the fifth ligand to iron as opposed to nitrogen of histidine or oxygen of tyrosine. A more subtle difference is that the P450 enzymes are activated when substrate is bound in the active site, whereas substrates diffuse into the active sties of "activated" peroxidase and catalase enzymes. Compound I analogues in peroxidases and biomimetic porphyrin-iron models are relatively
\end{abstract}


low reactivity oxidizing species, and the high reactivity of $\mathrm{P} 450$ oxidants typically has been ascribed to a counterion effect of the thiolate ligand that strongly activates the Compound I derivative by weakening the iron-oxygen bond. ${ }^{2}$

One peroxidase enzyme, chloroperoxidase (CPO) from Caldariomyces fumago, contains a cysteine thiolate ligand to iron. $9,10 \mathrm{CPO}$ is the only known thiolate-heme enzyme that gives a well-characterized Compound I species, which has been studied by visible absorption, 11 Mössbauer, ${ }^{12}$ resonance Raman, ${ }^{13}$ EPR, ${ }^{12}$ ENDOR, ${ }^{14}$ and XAFS ${ }^{15}$ spectroscopies. Compound I of CPO is often considered to be the best model available for the putative Compound I in P450 enzymes, ${ }^{16}$ and it catalyzes two-electron, oxo-transfer oxidation reactions that mimic those catalyzed by P450 enzymes. ${ }^{17,18}$ Limited kinetics of one-electron oxidations by CPO Compound I were reported, ${ }^{19}$ and no kinetic information for two-electron oxidation reactions was available, however. We report here kinetic studies of reactions of CPO Compound I with various two-electron reductants that provide benchmark data. Most of the substrates studied are known to be oxidized to alcohols, epoxides and hypohalides by CPO under turnover conditions. ${ }^{17,18,20}$ The general findings were that the rate constants for the CPO Compound I oxidation reactions are 2-3 orders of magnitude greater than those of models.

We isolated CPO from C. fumago and purified it by reported methods. ${ }^{21,22}$ The enzyme purity was evaluated from the $R / Z$ value $\left(\mathrm{A}_{400 \mathrm{~nm}} / \mathrm{A}_{280 \mathrm{~nm}}\right)$, and $\mathrm{CPO}$ with $\mathrm{R} / \mathrm{Z}>1.4$ was used. $\mathrm{CPO}$ was oxidized to the Compound I derivative in $>95 \%$ yield as described ${ }^{11}$ using $1.5-2.0$ equivalents of commercial peroxyacetic acid (32\%). ${ }^{23}$ The reported rate constant for oxidation of resting CPO with peroxyacetic acid is ca. $4 \times 10^{6} \mathrm{M}^{-1} \mathrm{~s}^{-1,24}$ and comparable rate constants were observed here. Figure S1 in Supporting Information shows typical UV-visible spectral changes upon oxidation of resting enzyme to the Compound I species.

The kinetics of CPO Compound I oxidation reactions were measured with a three-syringe, stopped-flow kinetic unit. The resting enzyme in $100 \mathrm{mM}$ potassium phosphate buffer ( $\mathrm{pH}$ 4.8) was mixed with the peroxyacetic acid solution. After $100 \mathrm{~ms}$ delay, the solution containing CPO Compound I was mixed with a solution containing a large excess of substrate. Kinetics were monitored at $400 \mathrm{~nm}$ (growth of Soret band of resting enzyme) or at $690 \mathrm{~nm}$ (decay of Q-band of Compound I). A typical time-resolved spectrum and kinetic traces are shown in Figure 1.

In the presence of a large excess of substrate, CPO Compound I decayed with pseudo-firstorder kinetics. Second-order rate constants were determined from Equation 1, where $k_{\mathrm{obs}}$ is the observed pseudo-first-order rate constant, $k_{0}$ is the background first-order rate constant for decay in the absence of substrate, $k_{\mathrm{OX}}$ is the second-order rate constant, and [Sub] is the molar concentration of substrate. Plots of $k_{\mathrm{obs}}$ versus [Sub] typically gave straight lines with nearzero intercepts; examples are shown in Figure 2. We measured the kinetics in three or four sets of studies for each substrate with three independent kinetic runs in each set of studies, and the second-order rate constants are listed in Table 1.

$$
k_{\mathrm{obs}}=k_{0}+k_{\mathrm{ox}}[\mathrm{Sub}]
$$

Several interesting features are seen in the second-order rate constants. Many substrates were oxidized successfully by CPO Compound I, and it is apparent that access to the active site was possible for all but the larger substrates, cis-stilbene and diphenylmethane (entries 17, 18). The seemingly large substrate 2-vinylnaphthalene displayed no retarding kinetic effect that might be ascribed to sterics, however (entry 12). The natural substrates chloride and bromide (entries $19,20)$ reacted very rapidly as expected. Chloride and bromide also are natural substrates for myeloperoxidase, and the rate constants for their reactions with myeloperoxidase Compound I at $\mathrm{pH} 7$ are $k=2.5 \times 10^{4} \mathrm{M}^{-1} \mathrm{~s}^{-1}$ and $k=1.1 \times 10^{6} \mathrm{M}^{-1} \mathrm{~s}^{-1}$, respectively. ${ }^{25}$ 
Recent studies suggest that Compound II of CPO is relatively basic. ${ }^{26}$ We evaluated $\mathrm{pH}$ effects on the reactivity of CPO Compound I. At six pH values in the range $\mathrm{pH} 3$ to $\mathrm{pH} 7$, we observed no effect on the rates of reaction of CPO Compound I with either styrene or methanol (see Supporting Information).

In general, the CPO Compound I kinetic results indicate an expected high reactivity of the ironoxo species due to the thiolate ligand. As shown by Raman spectroscopy, ${ }^{27}$ the $\mathrm{Fe}-\mathrm{O}$ bond strengths of Compound I species weaken as the counterion binding strength increases, which results in increased reactivity of iron-oxo species with stronger binding anions. The kinetic effect of the thiolate counterion in CPO Compound I is large. For example, the second-order rate constants for oxidations of ethylbenzene by the Compound I models 1, 2, and $\mathbf{3}$ are 1.6, 4.5 , and $6.2 \mathrm{M}^{-1} \mathrm{~s}^{-1}$, respectively, ${ }^{28,29}$ whereas CPO Compound I reacts with PhEt with a rate constant that is $2-3$ orders of magnitude greater (entry 2). Similarly, the rate constant for epoxidation of styrene by CPO Compound I (entry 7) is 600 and 3200 times greater than the rate constants for oxidation of styrene by $\mathbf{2}$ and $\mathbf{1}$, respectively. ${ }^{28}$ A thiolate-substituted model porphyrin-iron complex was reported to oxidize substrates about 2 orders of magnitude faster than tetraphenylporphyrin-iron(III) chloride under turnover conditions, ${ }^{30}$ but those rates of oxidation might reflect a combination of rates for oxidations of the catalysts by the sacrificial oxidants and substrate oxidation reactions.

The kinetic isotope effects observed for oxidations of nondeuterated and perdeuterated ethylbenzene and methanol (entries 2-5) reflect the high reactivity and concomitant low selectivity of the CPO Compound I species. For ethylbenzene, $k_{\mathrm{H}} / k_{\mathrm{D}}=2.6$, which can be compared to a value of $k_{\mathrm{H}} / k_{\mathrm{D}}=4.4$ for oxidations of ethylbenzene and ethylbenzene- $d_{10}$ by the model Compound I species $3 .{ }^{29}$ For methanol, a similar small kinetic isotope effect was observed, i.e. $k_{\mathrm{H}} / k_{\mathrm{D}}=3.2$.

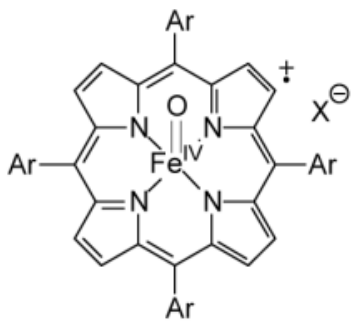

1: $\mathrm{Ar}=\mathrm{Me}_{3} \mathrm{C}_{6} \mathrm{H}_{2}, \mathrm{X}=\mathrm{ClO}_{4}$

2: $\mathrm{Ar}=\mathrm{Me}_{3} \mathrm{C}_{6} \mathrm{H}_{2}, \mathrm{X}=\mathrm{Cl}$

3: $\mathrm{Ar}=\mathrm{F}_{5} \mathrm{C}_{6}, \mathrm{X}=\mathrm{ClO}_{4}$

A further reflection of the high reactivity of CPO Compound I is seen in the linear Hammett plot for oxidations of the series of substituted styrenes in entries 7-11 (Figure 3). For the model oxidant species 1 with a weakly binding counterion perchlorate, the $\rho^{+}$value was $-1.96,{ }^{28}$ which is similar to the values found with other Compound I species with weak binding counterions. 31,32 For model oxidant species 2 with the stronger binding counterion chloride, $\rho^{+}=-0.89,28$ again a value similar to that for other chloride complexed Compound I species. 32,33 For CPO Compound I, however, $\rho^{+}=-0.28$, which is the smallest $\rho^{+}$value yet found for oxo transfer reactions from porphyrin-metal-oxo species.

One of the more noteworthy aspects of the CPO Compound I kinetics is the fact that no reaction was apparent with lauric acid (entry 16). The successful oxidation of 10-undecenoic acid with a rate constant similar to that for oxidations of other alkenes (entries 13-15) suggests that the long hydrocarbon chain in this substrate, and by analogy the hydrocarbon chain of lauric acid, readily accessed the CPO Compound I active site. We observed no increase in the rate of decay of CPO Compound I species in the presence of lauric acid, however. A pseudo-first-order rate constant of $k_{\mathrm{obs}}=1 \mathrm{~s}^{-1}$, which would result from a second-order rate constant for reaction of $1 \mathrm{mM}$ laurate of $k_{\mathrm{ox}}=500 \mathrm{M}^{-1} \mathrm{~s}^{-1}$ as found for toluene, would have been measured readily in these studies. Thus, the limit for the free energy of activation for the oxidation of lauric acid 
is $\Delta G^{\ddagger}>13.5 \mathrm{kcal} / \mathrm{mol}$. In contrast, low temperature studies of camphor oxidations by $\mathrm{P} 450_{\text {cam }}$ suggest that functionalization of the unactivated $\mathrm{C}-\mathrm{H}$ bond in the substrate has a small activation energy. ${ }^{4-6}$

An apparent attenuated reactivity of CPO Compound I in comparison to the P450 oxidants is indicated in our kinetic results in general. The second-order rate constants we obtained for reactions of CPO Compound I clearly are not diffusional rate constants, which would be found if the oxidation reactions were so fast that substrate could not leave the active site. If that were the case, then the measured second-order rate constants would be much greater than found here, substrates of similar size would react with the same rate constants, the slope of the Hammett plot in Figure 3 would be zero, and kinetic isotope effects of $k_{\mathrm{H}} / k_{\mathrm{D}}=1.0$ would be found. In contrast, the catalytic sequence for P450 enzymes is triggered only after the substrate is bound in the active site, and the substrate does not escape from the active site after the oxidant is formed.

The kinetic results for CPO Compound I two-electron oxidations of organic substrates provide kinetic and energetic information that is relevant to the $\mathrm{P} 450$ oxidants. The thiolate ligand in CPO Compound I results in acceleration of oxidation reactions in comparison to Compound I models with weaker binding counterions, ${ }^{28}$ but the reactivity of this transient apparently is not as great as that required for the true oxidants in P450s. The CPO results are similar to the finding in a recent study where a cytochrome $\mathrm{P} 450$ Compound I species produced via a photooxidation reaction from the Compound II species was found not to react with lauric acid even though laurate is a substrate for the $\mathrm{P} 450$ under catalytic turnover conditions. ${ }^{34}$ One possible explanation for these results is that the active oxidant in P450 enzymes is not a Compound I species but a high energy isomer of Compound I, i.e. a highly reactive iron(V)-oxo species. $35-37$

\section{Supplementary Material}

Refer to Web version on PubMed Central for supplementary material.

\section{Acknowledgements}

A portion of this work was supported in part by a grant from the National Institutes of Health (GM48722 to MN).

\section{References}

1. Ortiz de Montellano, PR., editor. Cytochrome P450 Structure, Mechanism, and Biochemistry. 3. Kluwer Academic; New York: 2005.

2. Sono M, Roach MP, Coulter ED, Dawson JH. Chem Rev 1996;96:2841-2887. [PubMed: 11848843]

3. Denisov IG, Makris TM, Sligar SG, Schlichting I. Chem Rev 2005;105:2253-2277. [PubMed: 15941214]

4. Davydov R, Macdonald IDG, Makris TM, Sligar SG, Hoffman BM. J Am Chem Soc 1999;121:1065410655.

5. Davydov R, Makris TM, Kofman V, Werst DE, Sligar SG, Hoffman BM. J Am Chem Soc 2001;123:1403-1415. [PubMed: 11456714]

6. Denisov IG, Makris TM, Sligar SG. J Biol Chem 2001;276:11648-11652. [PubMed: 11152470]

7. Dawson JH. Science 1988;240:433-439. [PubMed: 3358128]

8. Hiner ANP, Raven EL, Thorneley RNF, Garcia-Canovas F, Rodriguez-Lopez JN. J Inorg Biochem 2002;91:27-34. [PubMed: 12121759]

9. Morris DR, Hager LP. J Biol Chem 1966;241:1763-1768. [PubMed: 5949836]

10. Sundaramoorthy M, Terner J, Poulos TL. Structure 1995;3:1367-1377. [PubMed: 8747463]

Org Lett. Author manuscript; available in PMC 2008 September 13. 
11. Palcic MM, Rutter R, Araiso T, Hager LP, Dunford HB. Biochem Biophys Res Commun 1980;94:1123-1127. [PubMed: 7190391]

12. Rutter R, Hager LP, Dhonau H, Hendrich M, Valentine M, Debrunner P. Biochemistry 1984;23:6809_ 6816. [PubMed: 6099143]

13. Egawa T, Proshlyakov DA, Miki H, Makino R, Ogura T, Kitagawa T, Ishimura Y. J Biol Inorg Chem 2001;6:46-54. [PubMed: 11191222]

14. Kim SH, Perera R, Hager LP, Dawson JH, Hoffman BM. J Am Chem Soc 2006;128:5598-5599. [PubMed: 16637602]

15. Stone KL, Behan RK, Green MT. Proc Natl Acad Sci USA 2005;102:16563-16565. [PubMed: 16275918]

16. Van Rantwijk F, Sheldon RA. Curr Opin Biotech 2000;11:554-564. [PubMed: 11102789]

17. Zaks A, Dodds DR. J Am Chem Soc 1995;117:10419-10424.

18. Hager LP, Lakner FJ, Basavapathruni A. J Mol Catal B Enzym 1998;5:95-101.

19. Lambeir AM, Dunford HB, Pickard MA. Eur J Biochem 1987;163:123-127. [PubMed: 3816791]

20. Wagenknecht HA, Woggon WD. Chem Biol 1997;4:367-372. [PubMed: 9195874]

21. Hollenberg PF, Hager LP. Meth Enzymol 1978;52:521-529. [PubMed: 566840]

22. Hashimoto A, Pickard MA. J Gen Microbiol 1984;130:2051-2058.

23. The concentration of peroxyacetic acid was determined by iodometric titration.

24. Araiso T, Rutter R, Palcic MM, Hager LP, Dunford HB. Can J Biochem 1981;59:233-236. [PubMed: 7195767]

25. Furtmüller PG, Burner U, Obinger C. Biochemistry 1998;37:17923-17930. [PubMed: 9922160]

26. Green MT, Dawson JH, Gray HB. Science 2004;304:1653-1656. [PubMed: 15192224]

27. Czarnecki K, Nimri S, Gross Z, Proniewicz LM, Kincaid JR. J Am Chem Soc 1996;118:2929-2935.

28. Pan Z, Zhang R, Newcomb M. J Inorg Biochem 2006;100:524-532. [PubMed: 16500709]

29. Zhang R, Chandrasena REP, Martinez E II, Horner JH, Newcomb M. Org Lett 2005;7:1193-1195. [PubMed: 15760172]

30. For studies with thiolate-ligated iron-porphyrin models, see: (a) Higuchi T, Uzu S, Hirobe M. J Am Chem Soc 1990;112:7051-7053. (b) Higuchi T, Shimada K, Maruyama N, Hirobe M. J Am Chem Soc 1993;115:7551-7552. (c) Urano Y, Higuchi T, Hirobe M, Nagano T. J Am Chem Soc 1997;119:12008-12009. (d) Suzuki N, Higuchi T, Nagano T. J Am Chem Soc 2002;124:9622-9628. [PubMed: 12167058]

31. Groves JT, Watanabe Y. J Am Chem Soc 1986;108:507-508.

32. Song WJ, Ryu YO, Song R, Nam W. J Biol Inorg Chem 2005;10:294-304. [PubMed: 15827730]

33. Lindsay Smith JR, Sleath PR. J Chem Soc, Perkin Trans 2;1982:1009-1015.

34. Newcomb M, Zhang R, Chandrasena REP, Halgrimson JA, Horner JH, Makris TM, Sligar SG. J Am Chem Soc 2006;128:4580-4581. [PubMed: 16594688]

35. Newcomb M, Chandrasena REP. Biochem Biophys Res Commun 2005;338:394-403. [PubMed: 16168951]

36. Harischandra DN, Zhang R, Newcomb M. J Am Chem Soc 2005;127:13776-13777. [PubMed: 16201783]

37. Pan Z, Zhang R, Fung LW-M, Newcomb M. Submitted for publication

Org Lett. Author manuscript; available in PMC 2008 September 13. 


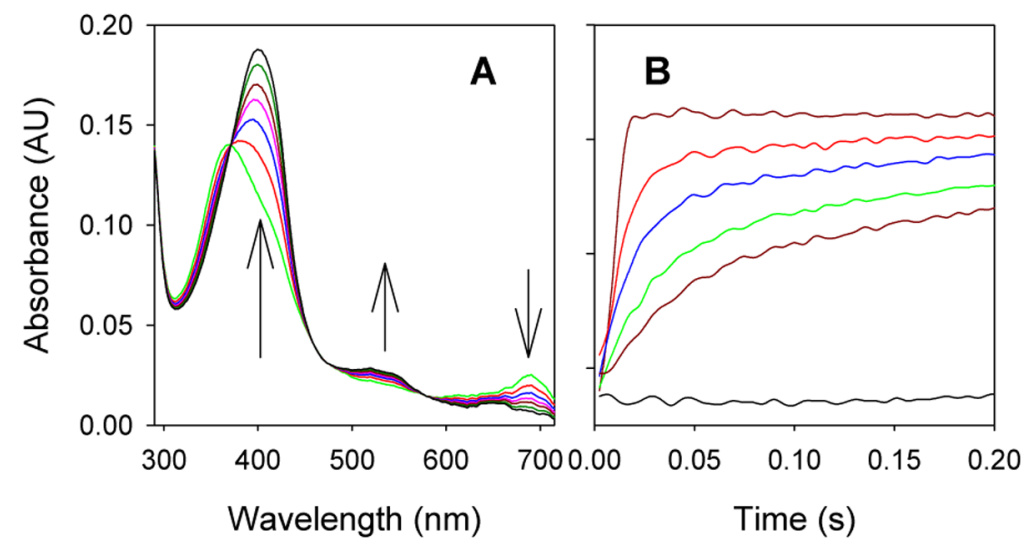

Figure 1.

(A) Time-resolved UV-vis spectrum for reaction of CPO Compound I with $0.10 \mathrm{mM}$ styrene over $330 \mathrm{~ms}$. (B) Kinetic traces at $400 \mathrm{~nm}$ for reactions of CPO Compound I with styrene at (from the bottom) $0,0.10,0.20,0.40,0.8$ and $1.6 \mathrm{mM}$ concentrations. 


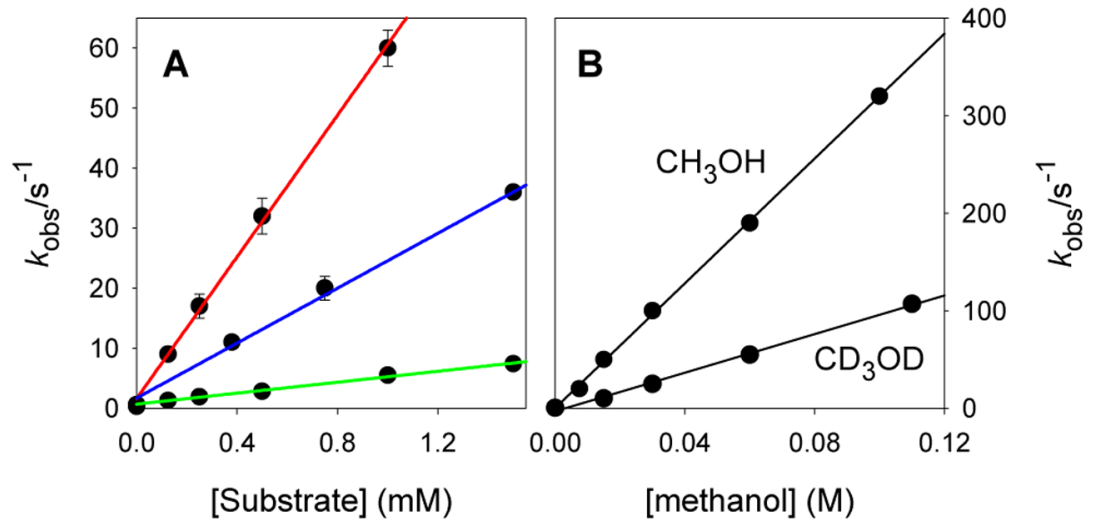

Figure 2.

(A) Observed rate constants for reactions of CPO Compound I with styrene (red), cinnamyl alcohol (blue), and 2-methyl-1-heptene (green). (B) Observed rate constants for reactions of CPO Compound I with methanol. 


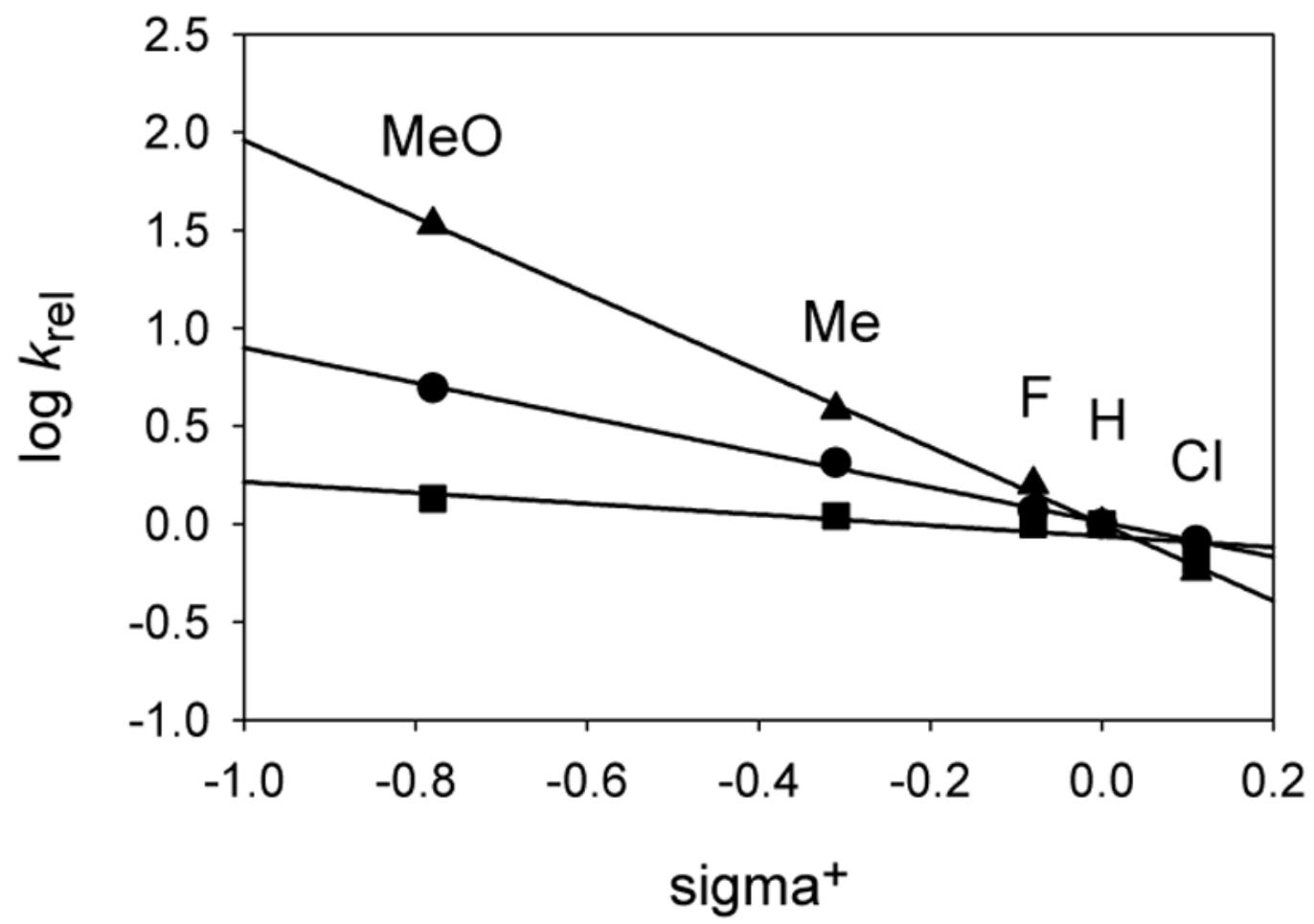

Figure 3.

Hammett plots for reactions of para-substituted styrenes with the model Compound I species 1 (triangles), the model Compound I species 2 (circles), and CPO Compound I (squares). The data for species $\mathbf{1}$ and $\mathbf{2}$ are from ref 28 . 
Table 1

Second-Order Rate Constants for Reactions of CPO Compound I with Two-Electron Reductants ${ }^{a}$

\begin{tabular}{|c|c|c|}
\hline entry & substrate & $k_{\mathrm{ox}}\left(\mathrm{M}^{-1} \mathrm{~s}^{-1}\right)$ \\
\hline $\begin{array}{r}1 \\
2 \\
3 \\
4 \\
5 \\
6 \\
7 \\
8 \\
9 \\
10 \\
11 \\
12 \\
13 \\
14 \\
15 \\
16 \\
17 \\
18 \\
19 \\
20\end{array}$ & $\begin{array}{l}\text { toluene } \\
\text { ethylbenzene } \\
\text { ethylbenzene- } d_{10} \\
\text { methanol } \\
\text { methanol- } d_{4} \\
\text { cinnamyl alcohol } \\
\text { styrene } \\
\text { 4-chlorostyrene } \\
\text { 4-fluorostyrene } \\
\text { 4-methylstyrene } \\
\text { 4-methoxystyrene } \\
\text { 2-vinylnaphthalene } \\
\text { 2-methyl-1-heptene } \\
\text { 2-methyl-2-heptene } \\
\text { 10-undecenoic acid } \\
\text { lauric acid } \\
\text { cis-stilbene } \\
\text { diphenylmethane } \\
\text { chloride } \\
\text { bromide }\end{array}$ & $\begin{array}{c}(5.5 \pm 0.2) \times 10^{2} \\
(9.6 \pm 0.2) \times 10^{2} \\
(3.7 \pm 0.5) \times 10^{2} \\
(3.2 \pm 0.1) \times 10^{3} \\
(9.9 \pm 0.1) \times 10^{2} \\
(2.3 \pm 0.1) \times 10^{4} \\
(6.1 \pm 0.5) \times 10^{4} \\
(4.0 \pm 0.3) \times 10^{4} \\
(6.1 \pm 0.4) \times 10^{4} \\
(6.7 \pm 0.6) \times 10^{4} \\
(8.3 \pm 0.5) \times 10^{4} \\
(1.1 \pm 0.1) \times 10^{5} \\
(4.3 \pm 0.4) \times 10^{3} \\
(3.6 \pm 0.2) \times 10^{3} \\
(6.4 \pm 0.5) \times 10^{3} \\
\mathrm{ND}^{b} \\
\mathrm{ND}^{b} \\
\mathrm{ND}^{b} \\
(2.5 \pm 0.1) \times 10^{4} \\
(3.8 \pm 0.1) \times 10^{5}\end{array}$ \\
\hline
\end{tabular}

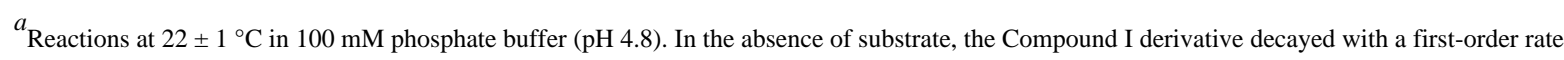
constant of ca. $0.5 \mathrm{~s}^{-1}$.

${ }^{b}$ Not detected; no acceleration in the rate of decay of Compound I was observed with these substrates; see Supporting Information. 